\title{
CRYSTAL STRUCTURES OF NOVEL BIS-NO-ACYCLIC SCHIFF BASE COMPOUNDS
}

\author{
A.D. Khalaji ${ }^{1}, K$. Fej farova ${ }^{2}, M$. Dušek ${ }^{2}$ \\ ${ }^{1}$ Department of Chemistry, Faculty of Science, Golestan University, Gorgan, Iran \\ E-mail: alidkhalaji@yahoo.com \\ ${ }^{2}$ Institute of Physics of the ASCR, Prague, Czech Republic
}

Novel bis-NO-acyclic Schiff base compounds are synthesized by the condensation of 3-methoxy-4-(2-(4-formyl-2-ethoxyphenoxy)ethoxy)benzaldehyde with 2-aminophenol $\left(\mathbf{L}^{\mathbf{1}}\right)$ or 4-aminophenol $\left(\mathbf{L}^{2}\right)$. The titled compounds with the monoclinic space group $C 2 / c$ are characterized by elemental analyses and single crystal X-ray diffraction.

\section{DOI: $10.15372 / \mathrm{JSC} 20150723$}

K e y w o r d s: Schiff base, characterized, single crystal, monoclinic.

A Schiff base, named after Hugo Schiff, is formed by the condensation of an amine group with the carbonyl group of an aldehyde or ketone. The mechanism of this reaction consists of the nucleophilic addition of the amine group to the carbonyl one, forming a hemiaminal, followed by a dehydration to generate an imine of the general formula R3R2C=NR1 [ 1-4]. Schiff bases can be used as ligands in coordination chemistry because of the basic character of $\pi$-acceptor properties of the imine nitrogen atom [ $5-8$ ]. The physical properties and reactivity of imines have been studied for more than a hundred years [9-11]. Furthermore, they are reported to show a variety of biological activities, including antibacterial, antifungal, anticancer, and herbicidal effects [12]. In recent year, various groups reported the inhibition effect of Schiff bases on steel and iron corrosion [ 13-16]. Recently, Khalil and co-workers have synthesized a new Schiff base derived from sulfanilamide that shows a reproducible change in its color due to the addition of acid and base and that can be used as an acid-base indicator [17]. Dalapati and co-workers report an anion receptor based on a Schiff base compound derived from $o$-phenylenediamine and 5-nitro-salicylaldehyde, which can selectively detect $\mathrm{F}^{-}$and $\mathrm{AcO}^{-}$ions by a naked-eye visible color change (colorless to yellow) [ 18 ]. In 2009 Hijji and coworkers reported a Schiff base as a calorimetric anion sensor which showed a selective coloration for $\mathrm{F}^{-}, \mathrm{AcO}^{-}, \mathrm{H}_{2} \mathrm{PO}_{4}^{-}$in acetonitrile and was selective to acetate in aqueous acetonitrile [19 ].

Recently, our group has reported the syntheses and crystal structures of Schiff base compounds $[4,20-25]$. Herein, we report the synthesis and the crystal structure determination of novel bis-NOacyclic Schiff base compounds, derived from 3-methoxy-4-(2-(4-formyl-2-ethoxyphenoxy)ethoxy)benzaldehyde with 2-aminophenol $\left(\mathbf{L}^{1}\right)$ or 4-aminophenol $\left(\mathbf{L}^{2}\right)$ (Scheme 1).

Experimental. Materials and instruments. All reagents and solvents for the synthesis and analysis were commercially available and used as received without further purifications. Infrared spectra were recorded using $\mathrm{KBr}$ disks on a FT-IR Perkin-Elmer spectrophotometer. Elemental analyses were carried out using a Heraeus CHN-O-Rapid analyzer. 3-Methoxy-4-(2-(4-formyl-2-ethoxyphenoxy)ethoxy)benzaldehyde was prepared following the literature procedure [26].

(C) Khalaji A.D., Fejfarova K., Dušek M., 2015 


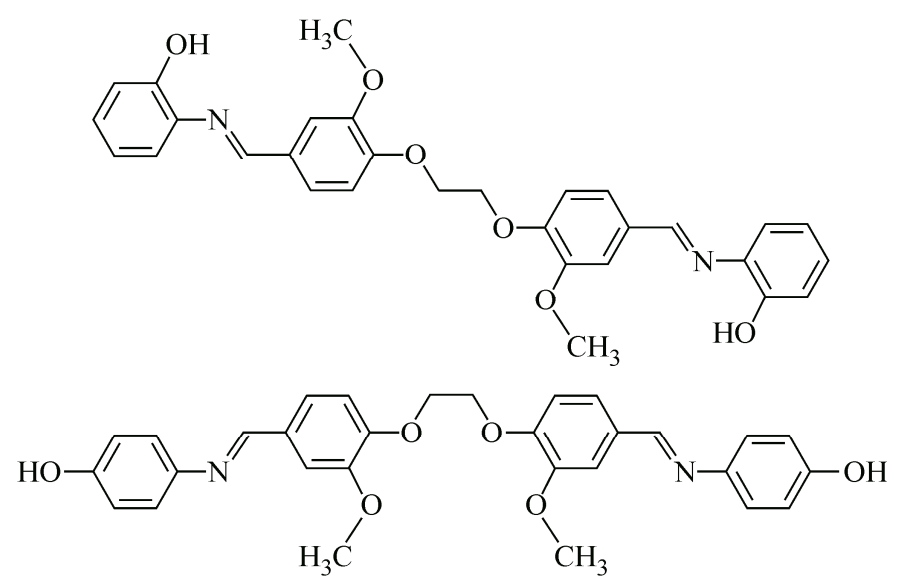

Scheme 1. Chemical structures of $\mathbf{L}^{1}$ and $\mathbf{L}^{2}$

Synthesis of $\mathbf{L}^{\mathbf{1}}$. 3-Methoxy-4-(2-(4formyl-2-ethoxyphenoxy)ethoxy)benzaldehyde $(0.2 \mathrm{mmol})$ and 2-aminophenol $(0.2 \mathrm{mmol})$ were dissolved in methanol at room temperature. The mixture was stirred and heated for 60 min to give a clear solution. The mixture was cooled and allowed to crystallize at room temperature. After keeping the solution in air for 4 days by slow evaporation of the solvent, pale yellow crystals formed at the bottom of the vessel. The resulting crystals were collected by filtration and dried at room temperature. Yield: $65 \%$. Anal. Calc. for $\mathrm{C}_{30} \mathrm{H}_{28} \mathrm{~N}_{2} \mathrm{O}_{6}$ : C 70.30, H 5.51, N $5.47 \%$. Found: C 70.35, H 5.56, N 5.51 \%.

Synthesis of $\mathbf{L}^{2}$. 3-Methoxy-4-(2-(4-formyl-2-ethoxyphenoxy)ethoxy)benzaldehyde (0.2 mmol) and 4-aminophenol $(0.2 \mathrm{mmol})$ were dissolved in methanol at room temperature. The mixture was stirred and heated for $60 \mathrm{~min}$ to give a clear solution. The mixture was cooled and allowed to crystallize at room temperature. After keeping the solution in air for four days by slow evaporation of the solvent, pale yellow crystals formed at the bottom of the vessel. The resulting crystals were collected by filtration and dried at room temperature. Yield: $65 \%$. Anal. Calc. for $\mathrm{C}_{30} \mathrm{H}_{28} \mathrm{~N}_{2} \mathrm{O}_{6}$ : C 70.30, H 5.51, N $5.47 \%$. Found: C 70.38, H 5.54, N $5.55 \%$.

Crystallographic analysis. A single crystal of the dimensions $0.38 \times 0.14 \times 0.09 \mathrm{~mm}$ of $\mathbf{L}^{\mathbf{1}}$ and the dimensions $0.54 \times 0.28 \times 0.13 \mathrm{~mm}$ of $\mathbf{L}^{2}$ was chosen for the X-ray diffraction study. Crystallographic measurements were performed at $120 \mathrm{~K}$ with a four-circle Oxford Diffraction Gemini CCD diffractometer with mirrors-collimated $\mathrm{Cu} K_{\alpha}$ radiation $(\lambda=1.54184 \AA)$. The crystal structure was solved by charge flipping using the SUPERFLIP program [27] and refined with the Jana2006 program package [28] by the full-matrix least-squares technique on $F^{2}$. The molecular structure plots were prepared by ORTEP III [29]. Hydrogen atoms were mostly discernible in difference Fourier maps and could be refined to reasonable geometry. According to common practice, hydrogen atoms attached to carbon atoms were kept in ideal positions during the refinement. The methyl hydrogen atoms were allowed to rotate freely about the adjacent $\mathrm{C}-\mathrm{C}$ bonds. The isotropic atomic displacement parameters of hydrogen atoms were set to $1.5 U_{\text {eq }}(\mathrm{C})$ for methyl groups and to $1.2 U_{\mathrm{eq}}(\mathrm{C}, \mathrm{N})$ for all other hydrogen atoms. Crystallographic data and details of the data collection and structure solution and refinements $\mathbf{L}^{\mathbf{1}}$ : $\mathrm{C}_{30} \mathrm{H}_{28} \mathrm{~N}_{2} \mathrm{O}_{6}, \quad M=512.6$, monoclinic, space group $C 2 / c, a=21.8589(14), \quad b=4.7995(4), \quad c=$ $=24.2047(18) \AA, \beta=104.496(6)^{\circ}, V=2458.5(3) \AA^{3}, Z=4, \mu=0.80 \mathrm{~mm}^{-1}, 11826$ measured reflections, 2195 independent, 1645 observed $(I>3 \sigma(I)), R_{\text {int }}=0.039, S=1.71, R\left(F^{2}>3 \sigma\left(F^{2}\right)\right)=0.053, w R\left(F^{2}\right)=$ $=0.145,175$ parameters, $\Delta \rho_{\max } / \Delta \rho_{\min }=0.42 /-0.21 \mathrm{e} / \AA^{3} . \mathbf{L}^{2}: \mathrm{C}_{30} \mathrm{H}_{28} \mathrm{~N}_{2} \mathrm{O}_{6}, M=512.6$, monoclinic, space group $C 2 / c, a=14.4284(11), b=9.9660(6), c=17.8616(9) \AA, \beta=101.807(5)^{\circ}, V=2514.0(3) \AA^{3}$, $Z=4, \mu=0.78 \mathrm{~mm}^{-1}, 9844$ measured reflections, 2243 independent, 1691 observed $(I>3 \sigma(I))$, $R_{\text {int }}=0.040, \quad S=1.63, \quad R\left(F^{2}>3 \sigma\left(F^{2}\right)\right)=0.050, \quad w R\left(F^{2}\right)=0.139,176$ parameters, $\Delta \rho_{\max } / \Delta \rho_{\min }=$ $=0.27 /-0.20 \mathrm{e} / \AA^{3}$.

Selected bond distances and angles are listed in Tables 1 and 2, respectively.

Results and discussion. The molecular structures of the titled compounds $\mathbf{L}^{1}$ and $\mathbf{L}^{2}$ with the atom numbering scheme are given in Figs. 1 and 2, respectively. Bond distances and angles (Tables 1 and 2) are in good agreement with the reports on similar compounds [20-25]. The bond distances $\mathrm{N} 1-\mathrm{C} 7(1.263(3) \AA)$ and $\mathrm{N} 1-\mathrm{C} 1(1.419(3) \AA)$ in $\mathbf{L}^{1}$ and $\mathrm{N} 1-\mathrm{C} 9(1.267(3) \AA)$ and $\mathrm{N} 1-\mathrm{C} 10$ $(1.429(3) \AA)$ in $\mathbf{L}^{2}$ are consistent with the distances of the $\mathrm{C}-\mathrm{N}$ double and single bonds [20-25 ]. The bond angles $\mathrm{N} 1-\mathrm{C} 7-\mathrm{C} 8\left(123.9(2)^{\circ}\right)$ and $\mathrm{C} 7-\mathrm{N} 1-\mathrm{C} 1\left(121.0(2)^{\circ}\right)$ in $\mathbf{L}^{1}$ and $\mathrm{N} 1-\mathrm{C} 9-\mathrm{C} 1$ 
Selected bond distances $(\AA)$ and angles (deg.) of $\mathbf{L}^{1}$

\begin{tabular}{|c|c|c|c|c|c|c|c|}
\hline $\mathrm{O} 1 \mathrm{C} 2$ & $1.358(3)$ & $\mathrm{O} 3 \mathrm{C} 15$ & $1.443(2)$ & $\mathrm{C} 10 \mathrm{O} 2 \mathrm{C} 14$ & $115.78(17)$ & $\mathrm{O} 2 \mathrm{C} 10 \mathrm{C} 9$ & $125.33(18)$ \\
\hline $\mathrm{O} 2 \mathrm{C} 10$ & $1.360(3)$ & $\mathrm{N} 1 \mathrm{C} 1$ & $1.419(3)$ & $\mathrm{C} 11 \mathrm{O} 3 \mathrm{C} 15$ & $116.13(17)$ & $\mathrm{O} 2 \mathrm{C} 10 \mathrm{C} 11$ & $114.88(18)$ \\
\hline $\mathrm{O} 2 \mathrm{C} 14$ & $1.436(3)$ & $\mathrm{N} 1 \mathrm{C} 7$ & $1.263(3)$ & $\mathrm{C} 1 \mathrm{~N} 1 \mathrm{C} 7$ & $121.0(2)$ & $\mathrm{O} 3 \mathrm{C} 11 \mathrm{C} 10$ & $115.56(19)$ \\
\hline $\mathrm{O} 3 \mathrm{C} 11$ & $1.360(2)$ & $\mathrm{C} 15 \mathrm{C} 15^{\mathrm{i}}$ & $1.501(3)$ & $\mathrm{N} 1 \mathrm{C} 1 \mathrm{C} 2$ & $114.8(2)$ & $\mathrm{O} 3 \mathrm{C} 11 \mathrm{C} 12$ & $124.83(18)$ \\
\hline & & & & N1C1C6 & $127.5(2)$ & $\mathrm{O} 3 \mathrm{C} 15 \mathrm{C} 15^{\mathrm{i}}$ & $105.63(17)$ \\
\hline \multirow{2}{*}{\multicolumn{4}{|c|}{$\overline{\text { Symmetry codes: }}{ }^{\mathrm{i}}-x,-y, 1-z$. }} & $\mathrm{O} 1 \mathrm{C} 2 \mathrm{C} 1$ & $120.2(2)$ & $\mathrm{N} 1 \mathrm{C} 7 \mathrm{C} 8$ & $123.9(2)$ \\
\hline & & & & $\mathrm{O} 1 \mathrm{C} 2 \mathrm{C} 3$ & $118.8(2)$ & & \\
\hline
\end{tabular}

Table 2

Selected bond distances $(\AA)$ and angles (deg.) of $\mathbf{L}^{2}$

\begin{tabular}{l|l||l|l|l|l||l|l}
\hline $\mathrm{O} 3 \mathrm{C} 13$ & $1.365(3)$ & $\mathrm{O} 2 \mathrm{C} 8$ & $1.440(2)$ & $\mathrm{C} 3 \mathrm{O} 1 \mathrm{C} 7$ & $117.65(19)$ & $\mathrm{O} 1 \mathrm{C} 3 \mathrm{C} 4$ & $114.43(18)$ \\
$\mathrm{O} 1 \mathrm{C} 3$ & $1.377(3)$ & $\mathrm{N} 1 \mathrm{C} 9$ & $1.267(3)$ & $\mathrm{C} 4 \mathrm{O} 2 \mathrm{C} 8$ & $117.27(16)$ & $\mathrm{O} 1 \mathrm{C} 3 \mathrm{C} 2$ & $125.08(18)$ \\
$\mathrm{O} 1 \mathrm{C} 7$ & $1.425(3)$ & $\mathrm{N} 1 \mathrm{C} 10$ & $1.429(3)$ & $\mathrm{C} 10 \mathrm{~N} 1 \mathrm{C} 9$ & $118.4(2)$ & $\mathrm{O} 2 \mathrm{C} 4 \mathrm{C} 3$ & $114.79(18)$ \\
$\mathrm{O} 2 \mathrm{C} 4$ & $1.353(3)$ & $\mathrm{C} 8 \mathrm{C} 8{ }^{\mathrm{i}}$ & $1.489(3)$ & $\mathrm{N} 1 \mathrm{C} 10 \mathrm{C} 11$ & $126.0(2)$ & $\mathrm{O} 2 \mathrm{C} 4 \mathrm{C} 5$ & $125.45(17)$ \\
& & $\mathrm{N} 1 \mathrm{C} 10 \mathrm{C} 15$ & $116.4(2)$ & $\mathrm{O} 2 \mathrm{C} 8 \mathrm{C} 8^{\mathrm{i}}$ & $107.33(16)$ \\
\multicolumn{2}{l}{ Symmetry codes: ${ }^{\mathrm{i}}-x,-y, 1-z}$. & $\mathrm{O} 3 \mathrm{C} 13 \mathrm{C} 12$ & $123.0(2)$ & $\mathrm{N} 1 \mathrm{C} 9 \mathrm{C} 1$ & $123.5(2)$ \\
\end{tabular}

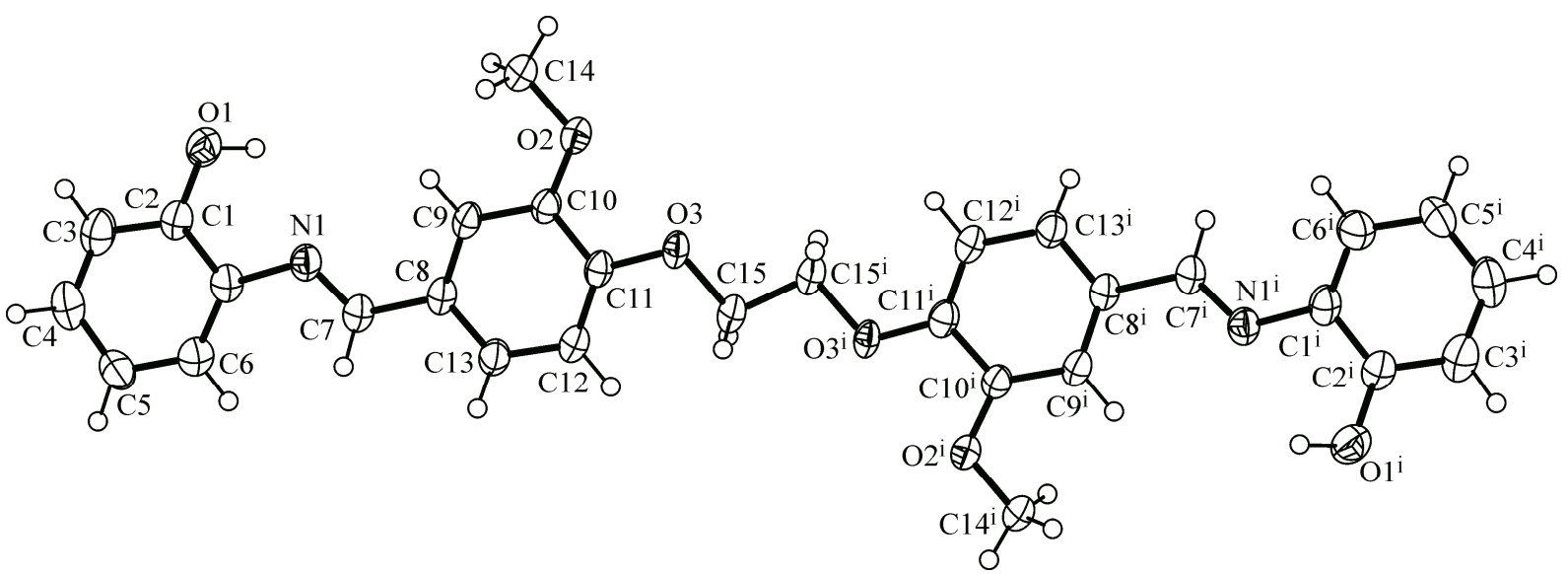

Fig. 1. ORTEP view of $\mathbf{L}^{1}$ with $50 \%$ probability displacement ellipsoids and atomic numbering

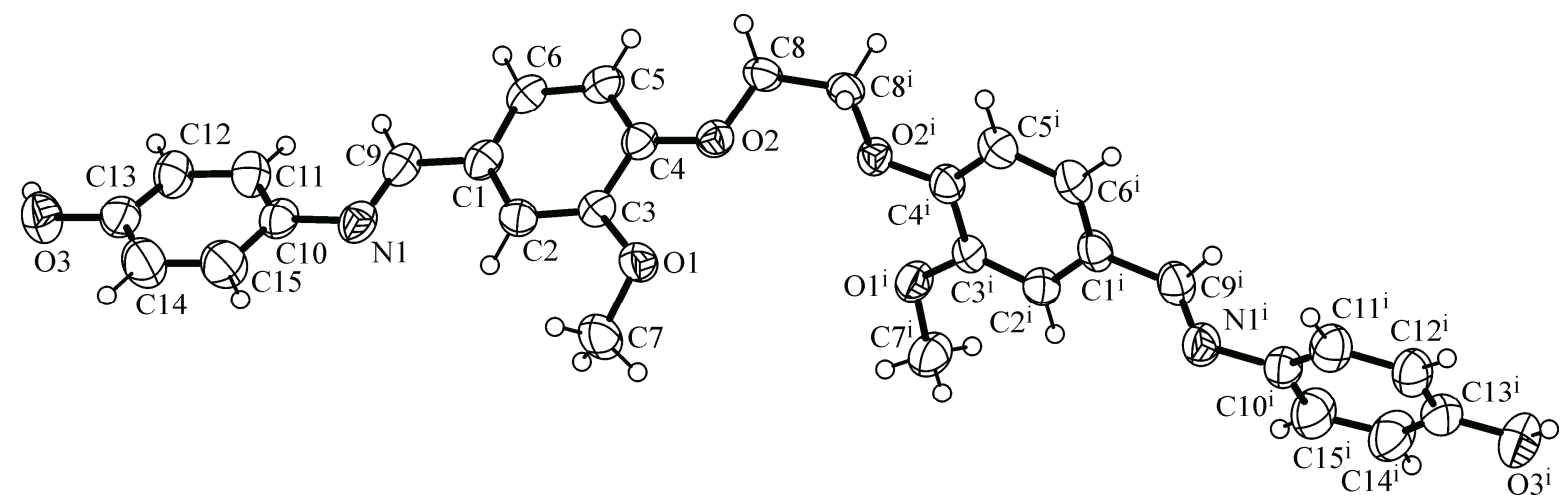

Fig. 2. ORTEP view of $\mathbf{L}^{2}$ with $50 \%$ probability displacement ellipsoids and atomic numbering 
T a b 1 e $3 \quad\left(123.5(2)^{\circ}\right)$ and $\mathrm{C} 10-\mathrm{N} 1-\mathrm{C} 9\left(118.4(2)^{\circ}\right)$ in $\mathbf{L}^{2}$ Hydrogen bond geometry ( $\AA$, deg.) for $\mathbf{L}^{1}$ and $\mathbf{L}^{2}$

\begin{tabular}{c|c|c|c|c|c}
\hline $\begin{array}{c}\text { Com- } \\
\text { pound }\end{array}$ & $D-\mathrm{H} \cdots A$ & $D-\mathrm{H}$ & $\mathrm{H} \cdots A$ & $D \cdots A$ & $D-\mathrm{H} \cdots A$ \\
\hline $\mathbf{L}^{1}$ & O1H1oO1 & $0.88(2)$ & $2.15(3)$ & $2.905(3)$ & $144(3)$ \\
$\mathbf{L}^{2}$ & O3H3oO1 & $0.91(2)$ & $1.93(3)$ & $2.817(3)$ & $166(3)$
\end{tabular}
are consistent with the $s p^{2}$ hybrid character of $\mathrm{C} 7$ and N1 atoms [20-25]. There is one intramolecular hydrogen bond of the $\mathrm{O}-\mathrm{H} \cdots \mathrm{N}$ type in the compounds $\mathbf{L}^{1}$ and $\mathbf{L}^{2}$ (Table 3 ).

Crystallographic data (excluding structure factors) for the structure reported in this paper have been deposited with the Cambridge Crystallographic Center, CCDC Nos. $1021021\left(\mathbf{L}^{1}\right)$ and $1021022\left(\mathbf{L}^{2}\right)$. Copies of the data can be obtained free of charge on application to the Director, CCDC, 12 Union Road, Cambridge CB2 1EZ, UK, fax: +44 1223336 033, e-mail: deposit@ccdc.cam.ac.uk or http:www.ccdc.cam.ac.uk.

We acknowledge the Golestan University (GU) for partial support of this work. Structure analysis was supported by project No.14-03276S of Czech Science Foundation.

\section{REFERENCES}

1. Fang Z., Cao C., Chen J., Deng X. // J. Mol. Struct. - 2014. - 1063. - P. 307 - 312.

2. Habibi M.H., Shojaee E., Nichol G.S. // Spectrochim. Acta. - 2012. - A98. - P. 396 - 404.

3. Marjani K., Mousavi M., Namazian F. // J. Chem. Crystallogr. - 2011. - 41. - P. 1451 - 1455.

4. Khalaji A.D., Fejfarova K., Dusek M. // J. Chem. Crystallogr. - 2012. - 42. - P. 263 - 266.

5. Unver H., Hayvali Z. // Spectrochim. Acta. - 2010. - A75. - P. 782 - 788.

6. Li Y.G., Dong X.W., Ai R., Xu X.L., Zhu H.L. // Russ. J. Coord. Chem. - 2011. - 37. - P. 523 - 527.

7. Ronson T.K., Adams H., Ward M.D. // Inorg. Chim. - 2005. - 358. - P. 1943 - 1954.

8. Khalaji A.D., Maghsodlou Rad., Grivani G., Das D. // J. Therm. Anal. Calorim. - 2011. - 103. - P. 747 751.

9. Abbas G., Irfan A., Mir M., Al-Rashida M., Khan AF. // J. Mol. Struct. - 2013. - 1050. - P. 10 - 14.

10. Sheikshoaie I., Saheb V. // Spectrochim. Acta. - 2010. - A77. - P. $1069-1076$.

11. Sun Y., Wang Y., Liu Z., Huang C., Yu C. // Spectrochim. Acta. - 2012. - A96. - P. 42 - 50.

12. da Silva C.M., da Silva D.L., Modolo L.V., Alves R.B., de Resende M.A., Martins C.V.B., de Fatima A. // J. Adv. Res. - 2011.- 2. - P. $1-8$.

13. Asan A., Soylu S., Tiyak T., Yildirim F., Oztas S.G., Ancim N., Kabasakaloglu M. // Corr. Sci. - 2006. - 48. - P. 3933 - 3944.

14. Emregul K.C., Atakol O. // Mat. Chem. Phys. - 2004. - 83. - P. 373 - 379.

15. Qu Q., Hao Z., Li L., Bai W., Liu Y., Ding Z. // Corros. Sci. - 2009. - 51. - P. 569 - 574.

16. Bayol E., Gurten T., Gurten A.A., Erbil M. // Mat. Chem. Phys. - 2008. - 112. - P. 624 - 630.

17. Khalil R.A., Jalil A.H., Abd-Alrazzak A.Y. // J. Iran Chem. Soc. - 2009. - 6. - P. 345 - 352.

18. Dalapati S.D., Alam M.A., Jana S., Guchhait N. // J. Fluorine. Chem. - 2011. - 132. - P. $536-540$.

19. Hijji Y.M., Barare B., Kennedy A.P., Butcher R. // Sens. Actuators. - 2009. - B136. - P. 297 - 302.

20. Khalaji A.D., Fejfarova K., Dusek M. // J. Struct. Chem. - 2011. - 52. - P. $1131-1133$.

21. Khalaji A.D., Fejfarova K., Dusek M., Bijanzadeh H.R. // J. Chem. Crystallogr. - 2011. - 41. - P. 1955 1960.

22. Khalaji A.D., Fejfarova K., Dusek M. // J. Cryst. Mineral. - 2013. - 21. - P. 5 - 10.

23. Khalaji A.D., Fejfarova K., Dusek M. // J. Struct. Chem. - 2011. - 52. - P. $835-840$.

24. Khalaji A.D., Fejfarova K., Dusek M., Najafi Chemahini A. // J. Chem. Crystallogr. - 2012. - P. 42136 140.

25. Khalaji A.D., Fejfarova K., Dusek M. // Acta Crystallogr. - 2012. - E68. - P. o2646.

26. Han J.R., Zhen X.L. // Acta Crystallogr. - 2005. - E61. - P. o4073.

27. Palatinus L., Chapuis G. // J. Appl. Crystallogr. - 2007. - 40. - P. 786.

28. Petrick V., Dusek M., Palatinus L. // Z. Kristallogr. -2014. - 229. - P. 345.

29. Farrugia L.J. // J. Appl. Crystallogr. - 1997. - 30. - P. 656. 